\title{
Effect of Organic Manures and Inorganic Fertilizers on Available Nutrient Status, Yield and Jaggery of Sugarcane
}

\author{
B. Vajantha*, N. V. Sarala, M. Hemanth Kumar and M. Subba Rao \\ Agricultural Research Station, Perumallapalle, Acharya N. G. Ranga Agricultural University, \\ Andhra Pradesh, India \\ *Corresponding author
}

\section{A B S T R A C T}

\section{Keywords}

Sugarcane, organic manures, chemical fertilizers, yield, quality and soil fertility.

\section{Article Info}

Accepted:

18 August 2019 Available Online:

10 September 2019
A field experiment was conducted during 2014-15 to study the impact of continuous application of organic manures and inorganic fertilizers on cane yield, jaggery yield, quality of sugarcane and soil fertility status after harvest at Agricultural Research Station, Perumallapalle, ANGRAU. The experiment consisted of two treatments i.e. organic and inorganic treatments. FYM and vermi compost were applied to organic treated plot based on $\mathrm{N}$ equivalent and recommended dose of fertilizers $\left(224: 112: 112 \mathrm{~kg} \mathrm{NPK} \mathrm{ha}^{-1}\right)$ were applied to inorganic treated plot. Yield and juice quality parameters were recorded at harvest. Soil samples were collected to determine available nutrient status at harvest. Results revealed that cane yield, cane length, Commercial Cane Sugar (CCS) \% and CCS yield were significantly affected by organic manures and inorganic fertilizers. The inorganic treated plot recorded higher cane yield $\left(97.4 \mathrm{t} \mathrm{ha}^{-1}\right)$, cane length $(264 \mathrm{~cm})$, CCS\% $(12.37 \%)$ and CCS yield $\left(11.03 \mathrm{t} \mathrm{ha}^{-1}\right)$ compared with organic treated plot $\left(92.6 \mathrm{t} \mathrm{ha}^{-1}\right.$ of cane yield, $251 \mathrm{~cm}$ of cane length, $12.10 \%$ of CCS and $10.09 \mathrm{t} \mathrm{ha}^{-1}$ of CCS yield). However Sucrose (16.17\%) was higher with application of organic manures than inorganic treated plot (15.92\%). Higher jaggery yield $\left(11.05 \mathrm{t} \mathrm{ha}^{-1}\right)$ was recorded with inorganic treated plot than organic plot $\left(10.09 \mathrm{t} \mathrm{ha}^{-1}\right)$. Regarding soil properties available nitrogen and potassium were significantly higher with organic treated plot $\left(244\right.$ and $265 \mathrm{~kg} \mathrm{ha}^{-1}$ of available nitrogen and potassium respectively) than inorganic plot (239 and $258 \mathrm{~kg}$ $\mathrm{ha}^{-1}$ of available nitrogen and potassium respectively).

\section{Introduction}

Addition of organic manures to soil creates a favorable environment where by crop shows a good response to all management practices.
Level of organic matter content of soil is the characteristic property of soil. Sugarcane soils in India shows a level of organic carbon varying from 0.4 to $1.0 \%$ (Srivastava, 2006). If it is difficult to build up permanently the 
organic matter content of soil in a small span of time. However short term benefits of addition of organic manures on soil fertility and productivity of soil can be achieved by increasing its content in soil by external application of organic manures. Exclusive use of chemical fertilizers under continuous cropping of sugarcane leads to depletion of soil health and also creates imbalance in the composition as well as availability of nutrients. In this connection the study was planned to know the effect of organic manures and chemical fertilizers on soil nutrient status, cane yield, yield attributing characters and quality of sugarcane.

\section{Materials and Methods}

A field experiment was conducted in sandy loam soils in permanent plots from 2012-13 to study the effect of organic manures on yield of sugarcane and soil nutrient status at Agricultural Research Station, Perumallapalle with a variety $2005 \mathrm{~T} 16$. Initially the experimental soil was neutral in reaction, normal in electrical conductivity, low organic carbon content and available nitrogen, medium in available phosphorus and high in available potassium (Table 3). The experimental plot was divided in to two equal plots with a plot size of $500 \mathrm{~m}^{2}$. Two plots considered as two treatments viz., inorganic and organic treatments. The organic manures FYM and VC applied based on $\mathrm{N}$ equivalent basis to organic treatment in last ploughing. The recommended dose of $\mathrm{N}, \mathrm{P}$ and $\mathrm{K}$ (224$112-112 \mathrm{~kg} \mathrm{ha}^{-1,}$ respectively) were applied in the form of urea, single super phosphate and muriate of potash to inorganic treatment. Entire $\mathrm{P}$ and $\mathrm{K}$ were applied at the time of planting. Nitrogen was applied in two equal splits at the time of planting and 45 days after planting.

The soil samples were collected after harvest of the crop from both the treatments and chemical analysis was done as per the procedures. $\mathrm{pH}$ and $\mathrm{EC}$ of the soil samples were determined in saturated paste using the procedure given by Jackson (1973). The organic carbon content of the $0.5 \mathrm{~mm}$ sieved soil samples was estimated by wet oxidation method given by Walkley and Black (1934). Available nitrogen in the soil samples was determined by alkaline potassium permanganate method (Subbiah and Asija, 1956). Available phosphorus in the soil samples was determined as per procedure described by Olsen et al., (1954). Available potassium in the soils were extracted with neutral normal ammonium acetate and determined by using the procedure given by Tandon (1973). Juice analysis was carried out prior to harvesting. Observations on juice quality i.e. sucrose, CCS\% and purity was estimated as per the method suggested by Meade and Chen (1971). The data was statistically analyzed by $\mathrm{t}$ - test (Panse and Sukhatme, 1985).

\section{Results and Discussion}

Data on yield and yield attributing characters during 2014-15 was presented in table 1. Among organic and inorganic plots, inorganic treated plot recorded significantly highest cane yield (97.4 $\left.\mathrm{t} \mathrm{ha}^{-1}\right)$. Cane length $(264 \mathrm{~cm}), \mathrm{CCS}$ $\%(12.37 \%)$ and CCS yield (11.03 $\left.\mathrm{tha}^{-1}\right)$ than organic treated plot $\left(92.6 \mathrm{t} \mathrm{ha}^{-1}\right.$ of cane yield, $251 \mathrm{~cm}$ of cane length, $12.10 \%$ of CCS and $10.09 \mathrm{t} \mathrm{ha}^{-1}$ of CCS yield).

The cane yield was higher in inorganic treated plot which indicated that the inorganic nutrient sources were more effective than organic nutrient sources in short tm. Jaggery yield was also observed to be higher in inorganic treatment. (11.05 $\left.\mathrm{t} \mathrm{ha}^{-1}\right)$ when compared with organic treatment (10.09 $\mathrm{t} \mathrm{ha}^{-1}$ ) (Table 2). The higher jaggery yield might be due to the highest cane yield produced under inorganic treatment. 
Table.1 Effect of organic farming on yield and quality of sugarcane

\begin{tabular}{|l|c|c|c|}
\hline \multicolumn{1}{|c|}{ Particulars } & Organic & Inorganic & t value \\
\hline Cane yield (t ha ) & 92.6 & 97.4 & 0.032 \\
\hline Cane length (cm) & 251 & 264 & $0.377^{*}$ \\
\hline Cane girth (cm) & 2.47 & 2.53 & 0.072 \\
\hline Sucrose (\%) & 16.17 & 15.92 & 0.147 \\
\hline CCS (\%) & 12.10 & 12.37 & $0.33 *^{*}$ \\
\hline Purity (\%) & 83.24 & 87.15 & 0.026 \\
\hline CCS yield (t ha ) & 10.09 & 11.03 & $0.003^{*}$ \\
\hline B:C ratio & 1.31 & 2.40 & \\
\hline
\end{tabular}

* significant at $\mathrm{P}=0.05$ level

Table.2 Effect of organic farming on yield and quality of jiggery

\begin{tabular}{|l|c|c|c|}
\hline \multicolumn{1}{|c|}{ Particulars } & Organic & Inorganic & t value \\
\hline Jaggerv vield $\left(\mathbf{t ~ h a ~}^{-\mathbf{- 1}}\right)$ & 10.09 & 11.05 & $0.324^{*}$ \\
\hline pH & 6.4 & 6.3 & 0.0401 \\
\hline EC $\left(\mathbf{d S ~ m}^{-\mathbf{1}}\right)$ & 0.246 & 0.231 & 0.051 \\
\hline Colour intensity & 22.4 & 25.1 & 0.026 \\
\hline Spindle brix & 11.2 & 10.9 & 0.191 \\
\hline Reducing sugars & 4.87 & 5.02 & 0.644 \\
\hline
\end{tabular}

Table.3 Initial soil fertility status.

\begin{tabular}{|c|c|}
\hline Particulars & Value \\
\hline Soil pH & 7.48 \\
\hline Soil EC(dS m $\left.{ }^{-1}\right)$ & 0.221 \\
\hline Available N (kg ha ${ }^{-1}$ ) & 206 \\
\hline Available $\mathrm{P}_{2} \mathrm{O}_{5}\left(\mathrm{~kg} \mathrm{ha}^{-1}\right)$ & 27.9 \\
\hline Available $\mathrm{K}$,O (kg ha $^{-1}$ ) & 284 \\
\hline Organic carbon $(\%)$ & 0.34 \\
\hline
\end{tabular}


Table. 4 Effect of organic farming on soil nutrient status after havest.

\begin{tabular}{|c|c|c|c|}
\hline Particulars & Organic & Inorganic & t value \\
\hline Soil pH & 7.32 & 7.18 & 0.031 \\
\hline Soil EC(dS m $\left.{ }^{-1}\right)$ & 0.221 & 0.209 & 0.043 \\
\hline Available N (kg ha ${ }^{-1}$ ) & 244 & 239 & $0.413 *$ \\
\hline Available $\mathrm{P}_{2} \mathrm{O}_{5}\left(\mathrm{~kg} \mathrm{ha}^{-1}\right)$ & 36.5 & 33.9 & 0.032 \\
\hline Available $K_{2} O\left(\mathrm{~kg} \mathrm{ha}^{-1}\right)$ & 318 & 310 & $0.089 *$ \\
\hline Organic carbon $(\%)$ & 0.48 & 0.44 & 0.020 \\
\hline
\end{tabular}

* significant at $\mathrm{P}=0.05$ level

Fig.1 Percent buildup of available nitrogen than initial value

\begin{tabular}{|c|c|c|}
\hline \multicolumn{3}{|c|}{ Available N } \\
\hline 185 & 18.44 & \\
\hline 18 & & \\
\hline 17.5 & & \\
\hline 17 & & \\
\hline 16.5 & & 16.01 \\
\hline & & \\
\hline 15.5 & & \\
\hline 15 & & \\
\hline & Organic & Inorganic \\
\hline
\end{tabular}


Fig.2 Percent buildup of available phosphorus than initial value

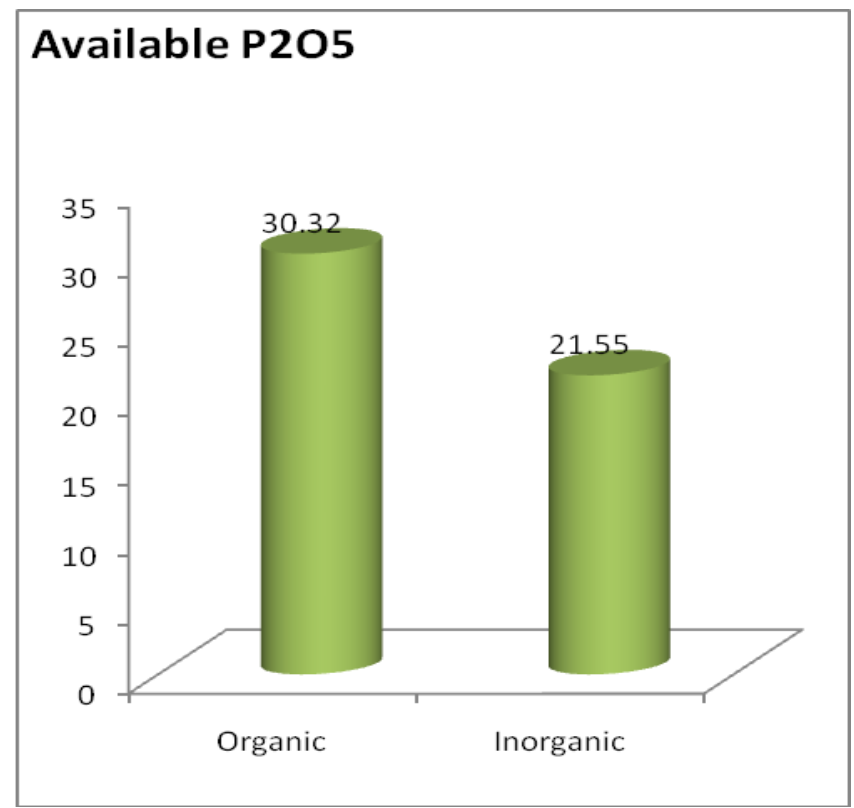

Fig.3 Percent buildup of available potassium than initial value

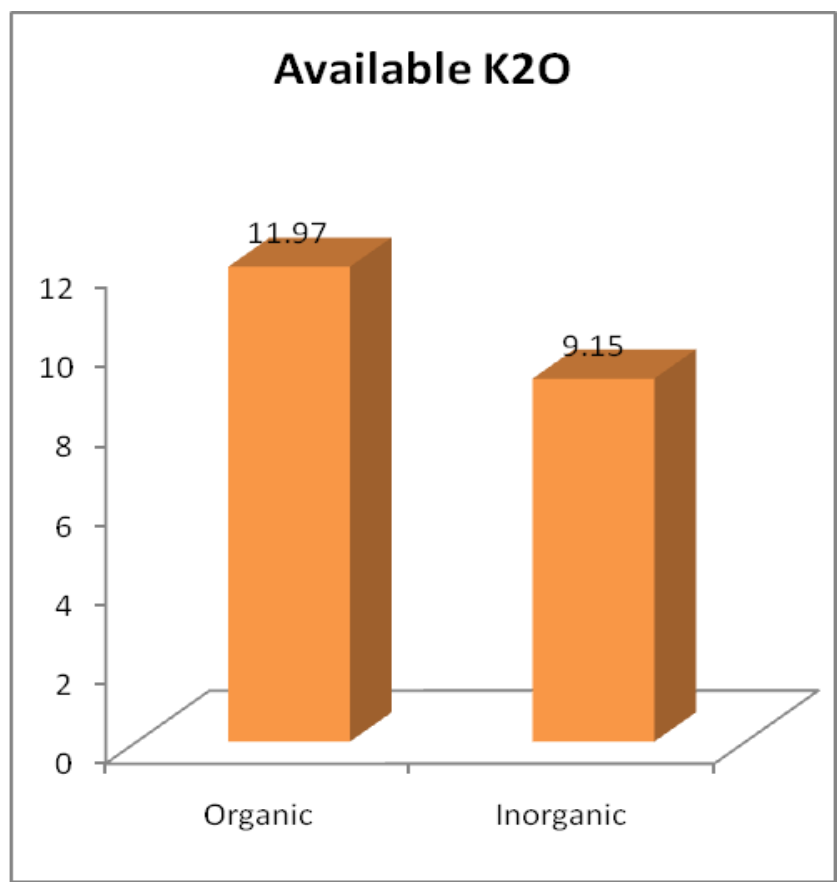

However high spindle brix (11.2), less colour intensity $(22.4 \%)$ and less reducing sugars $(4.87 \%)$ was observed in organic treatment when compared with inorganic treatment (10.9 of spindle brix, $25.1 \%$ of colour intensity and $5.02 \%$ of reducing sugars). Less colour intensity gives bright colour and high colour intensity gives dark colour. It indicated that good quality of jaggery was produced from organic treatment. Regarding to soil nutrient status available nitrogen and potassium are significantly affected by organic and inorganic 
treatments (Table 4). Higher available nitrogen $\left(244 \mathrm{~kg} \mathrm{ha}^{-1}\right)$, potassium $\left(318 \mathrm{~kg} \mathrm{ha}^{-1}\right)$ and organic carbon $(0.48 \%)$ were recorded with application of organic manures than inorganic fertilizers. The buildup of available nitrogen, phosphorus and potassium (18.44\%, $30.32 \%$ and $11.97 \%$, respectively) was observed in organic treated plot after harvest as against initial values. In inorganic treatment also buildup of available nitrogen, phosphorus and potassium $(16.01 \%, 21.55 \%$ and $9.15 \%$, respectively) when compared with initial values. The higher build up of organic carbon with organic treatment may be due to subsequent decomposition of applied organic manures. These results are in agreement with the findings of Verma and Mathur (2009) and Chesti et al., (2013). Further, the addition of FYM and vermi compost might have created environment conducive for formation of humic acid, which ultimately resulted in an increase in the organic carbon content of the soil (Bajpai et al., 2006). The increase in available $\mathrm{P}$ with organics could be ascribed to solubilizing effect on the native soil $\mathrm{P}$ and consequent contribution of the $\mathrm{P}$ as solubilized to labile pool. Incorporation of FYM, vermi compost and other manures increases the mineralization of organic $\mathrm{P}$ due to microbial action and enhanced mobility of $\mathrm{P}$ (Shilpa babar and Dongale 2013). Organic matter may also reduce the fixation of phosphate by providing protective cover on sesquioxides and thus reduce phosphate fixing capacity and increase the available $\mathrm{P}$ in soil (Prasad et al., 2010). The study showed that even though application of chemical fertilizers produced high cane yield, application of organic manures helps to improve organic carbon and sustain the yield in long term.

\section{References}

Bajpai, R. K., Chitale, S., Upadhyay, S. K., and Urkurkar, J. S., 2006. Long term studies on soil physic-chemical properties and productivity of ricewheat system as influenced by integrated nutrient management in Inceptisol of Chhattisgarh. Journal of the Indian society of Soil Science 54: 24-29.

Chesti, M. H., Anshuman kohli and Sharma, A. K., 2013. Effect of integrated nutrient management on yield and nutrient uptake by wheat and soil properties. Journal of the Indian society of Soil Science 61: 1-6.

Jackson, M.L., 1973. Soil Chemical Analysis. Oxford IBH Publishing House, Bombay.38.

Meade, G. P., and Chen, J. C. P., 1971. Cane Handbook $10^{\text {th }}$ edition, Johnwiley and Sons, New York. Olsen, S.R., Cole, C.V., Watanabe, F.S., and Dean, L.A., 1954. Estimation of available phosphorus in soils by extraction with sodium bicarbonate. Circular of United States Department of Agriculture. 939.

Panse, V.G., and Sukhatme, P.V., 1985. Statistical methods for Agricultural Research, New Delhi.

Prasad, J., Karnakar, S., Kumar, R., and Mishra., B 2010. Influence of integrated nutrient management on yield and soil properties in maizewheat cropping system in an Alfisol of Jharkhand. Journal of the Indian society of Soil Science 58: 200-204.

Shilpa babar, and Dongale., 2013. Effect of organic and inorganic fertilizers on soil fertility and crop productivity under Mustard-Cowpea-Rice cropping sequence on lateritic soils of konkan. Journal of the Indian society of Soil Science 61 (1):7-14.

Srivastava, A. K., 2006. Sugarcane at a glance. International Book Distributing Co., Lucknow pp 58.

Subbiah, B.V., and Asija, C.L. 1956. A rapid procedure for the estimation of 
available nitrogen in soils. Current Science. 25: 32.

Tandon, H. L. S., 1973. Methods of Analysis of Soils, Plants, Water and Fertilizers, FDCO, New Delhi.

Verma, G., and Mathur, A. K., 2009. Effect of integrated nutrient management on active pools of soil organic matter under maize-wheat system of a Typic Haplustept. Journal of the Indian ociety of Soil Science 57: 317-322.

Walkley, A., and Black, C.A. 1934. Estimation of organic carbon by chromic acid titration method. Soil science. 37: 29-34.

\section{How to cite this article:}

Vajantha, B., N. V. Sarala, M. Hemanth Kumar and Subba Rao, M. 2019. Agricultural Research Station, Perumallapalle AcharyaN.G.Ranga Agricultural University, Andhra Pradesh, India. Int.J.Curr.Microbiol.App.Sci. 8(09): 1456-1462.

doi: https://doi.org/10.20546/ijcmas.2019.809.167 